\title{
Implementasi Metode Sosiodrama dalam Mengasah Pelafalan Kalimat Anak Tunarungu Kelas XI
}

\author{
Ayu Yulistyani Fauziah, Rizqi Fajar Pradipta \\ Universitas Negeri Malang \\ E-mail : lis120494zia@gmail.com
}

\begin{abstract}
Abstrak: penggunaan sosiodrama dalam mengasah pelafalan kalimat pada anak tunarungu kelas XI SMALB-B YPTB Malang. Penelitian ini menggunakan rancangan penelitian ekperimen dengan desain Quasi ekperimental bentuk time series design, dengan Q1-Q4 pre test untuk mengukur hasil belajar sebelum menggunakan metode sosoidrama dan Q5-Q8 post test untuk mengukur hasil belajar setelah mengunakan metode sosiodrama. Penggunaan metode sosiodrama dalam pelajaran Bahasa Indonesia dapat diterapkan karena selain tujuan utamanya adalah melafalkan kalimat, tetapi juga dapat melatih anak tunarungu pada aspek motorik, konsentrasi, kesabaran, dan ketekunan.

Kata kunci: tunarungu, pelafalan kalimat, metode sosiodrama
\end{abstract}

\begin{abstract}
: reveal the influence of the use of sociodrama in sharpening sentences pronunciation for Hearing Impairment students of XI grade in SMALB-B YPTB Malang. This study used experimental design with Quasi experimental design, time series design, with Q1-Q4 pre test to measure learning result before using sociodrama method and Q5-Q8 post test to measure learning result after using sociodrama method. The use of sociodrama method in Indonesian Language lesson can be applied because besides the main purpose is to pronounce sentences, but also can train Hearing Impairment children on motoric aspect, concentration, patience, and persistence.
\end{abstract}

Keywords: Hearing Impairment, sentences pronunciation, sociodrama method

Pada dasarnya manusia adalah makhluk sosial, yaitu makluk yang tidak dapat sendiri memenuhi semua kebutuhan. Sebagai makhluk sosial manusia membutuhkan orang lain dan lingkungan untuk bersosialisasi. Salah satu alat yang sangat berperan penting dalam bersoaialisasi adalah berkomunikasi yaitu dengan bahasa. Melalui bahasa, manusia dapat berinteraksi dan berkomunikasi dengan lingkungan, masyarakat satu dan masyarakat lain. (Sadjaah. 1995), "Bahasa adalah suatu ciri pembeda utama antara manusia dengan makhluk lain di dunia ini". Dari pernyataan tersebut dapat disimpulkan bahwa untuk melakukan interaksi dan berkomunikasi dengan orang lain, seseorang harus memiliki keterampilan berbahasa yang baik, benar, dan jelas. Penguasaan struktur kalimat merupakan hal yang sangat penting, karena dengan struktur kalimat yang benar maka makna dari sebuah kalimat bisa dipahami, di samping itu komunikasi menjadi lebih efektif dan ef isien tidak terkecuali siswa tunarungu (Pradipta, 2017)

Masalah utama pada anak tunarungu adalah komunikasi karena kurang berfungsinya indra pendengaran sehingga mengurangi atau menghilangkan kemampuan komunikasi. Anak tuna rungu tidak dapat memperoleh bahasa dengan cara yang mudah. Dengan hal tersebut kosakata anak tunarungu jadi sedikit dan bahkan bisa salah menempatkan kata ketika merangkainya menjadi sebuah paragraf yang baik dan benar menurut tata Bahasa Indonesia. Bahasa merupakan alat komunikasi yang dipergunakan manusia dalam mengadakan hubungan dengan sesamanya. Ketajaman pendengaran sangat mempengaruhi proses bicara dan bahasa. Anak tunarungu akan mengalami hambatan yang cukup berat dalam hal ini karena proses peniruannya hanya terbatas pada peniruan visual, sehingga anak tunarungu memerlukan pembinaan secara khusus dan intensif sesuai dengan kemampuan dan taraf ketunarunguan. Pengembangan kemampuan bahasa dan komunikasi anak tunarungu harus melaui penglihatannya dan memanfaatkan sisa pendengarannya. Oleh sebab itu komunikasi bagi anak tunarungu mempergunakan segala aspek yang ada pada dirinya. Hambatan perkembangan bahasa yang dialami oleh anak tunarungu dapat berdampak pada kesulitan mereka dalam memaknai arti kata, sehingga anak ini bisa mengembangakan konsep kata melaui manipulasi gerak bibir.

Arti bahasa adalah bagian dari komunikasi dengan menggunakan sistim bahasa. Bahasa sebagai sitim dapat diuraikan sebagai berikut : a) bagaimana produksi bunyi bahasa dapat diucapkan dengan baik dan dapat didengar dengan jelas, b) bagaiman dengan fonem (bunyi bahasa) yang telah terangkai dalam bentuk kata menjadi bermakna sehingga pelaku komunikasi (penyampaian dan penerima pesan) dapat memahaminya, c) bagaimana kalimat yang tersusun secara efektif dan efisien bermanfaat bagi pemakai bahasa. Efektif adalah mempunyai makna bagi pelaku komunikasi. Kalimat efisien mengandung arti tercapainya sasaran sesuai dengan apa yang dimaksud (Sadjaah. 1995). Kalimat merupakan kata yang disusun 
secara utuh sehingga mengandung makna tersendiri. Jika kita menggunakan struktur kalimat yang benar maka pesan dalam kalimat tersebut akan mudah dipahami oleh orang lain dan orang lain akan mengerti kalimat yang kita bicarakan. Anak tunarungu memiliki keterbatasan dalam menginterpretasi kalimat karena kemampuan dalam menginterpretasi kalimat hanya bersandar pada pengalaman bahasanya yang terbatas. Anak tunarungu ketika berbicara maka kalimat yang akan diucapkan tidak terstruktur atau terbalik-balik sehingga orang lain kurang dapat memahami pesan yang disampaikan.

Hasil penelitian selama di lapangan adalah pelafalan kalimat yang diucapkan anak tunarungu tidaklah terucap dengan jelas sehingga sulit dipahami. Hal ini terjadi pada siswa tunarungu kelas XI. Pada saat mereka melakukan komunikasi, kebanyakan kata yang diucapkan tidaklah jelas pengucapan. Salah satu contohnya ada kasus yang ditujukkan oleh siswa tunarungu yaitu, "ayah saya pergi ke Surabaya"Ia ungkapkan "ayah aya pegi ke urabaya". Kata yang diungkapkan tersebut tidaklah jelas dalam pengungkapan, sehingga terjadi kesalah pahaman arti dan makna bagi orang lain. Apabila kasus tersebut tidak cepat ditangani, maka akan semakin bertambah banyak masalah yang dihadapi anak tunarungu. Karena semakin bertambah usia anak maka akan semakin serius pula masalah yang dihadapi anak tunarungu.

Berdasarkan permasalahan pada anak tunarungu tersebut, maka perlu adanya media atau metode pembelajaran sebagai alat bantu untuk mempermudah menyampaikan materi kepada anak tunarungu tentang pelafalan kata. Metode soisodrama merupakan salah satu metode pembelajaran yang dapat digunakan untuk meningkatkan kemampuan melafalkan kalimat. Metode sosiodrama diartikan sebagai suatu metode pemecahan masalah yang melibatkan dua orang atau lebih untuk mengambil keputusan secara terbuka dalam situasi yang dilematis. Pemeranan diakhiri pada saat mencapai titik dilema dan masing-masing pemeran bebas menganalisis apa yang terjadi melalui diskusi yang melibatkan para pengamat untuk mencari pemecahan Selain itu metode sosiodrama juga mempunyai beberapa manfaat antara lain a)Mengenali perasaan, b)Memperoleh inspirasi sikap, nilai dan persepsi, c)Mengembangkan sikap dan kemampuan memecahkan masalah, dan d)Menggali inti pelajaran melalui berbagai cara. Dari latar belakang di atas, peneliti ingin mencoba membantu siswa tunarungu dalam menghadapi masalah tersebut dengan melakukan penelitian “ Penggunaan Metode Sosiodrama dalam Mengasah Pelafalan Kalimat pada Siswa Tunarungu Kelas XI".

\section{METODE}

Desain penelitian merupakan suatu kerangka dalam melaksanakan penelitian. Kejelasan dari desain dapat mempengaruhi validitas data dan tingkat kepercayaan hasil penelitian. Jenis penelitian menggunakan eksperimen dengan desain Quasi eksperimental bentuk time series design, karena penelitian ini hanya menggunakan satu kelompok saja, sehingga tidak memerlukan kelompok kontrol.

Dalam desain kelompok ini kelompok yang digunakan untuk penelitian tidak dapat dipilih secara random. Sebelum diberi perlakuan. Kelompok diberi pre test sampai empat kali, dengan maksud untuk mengetahui kestabilan dan kejelasan keadaan keadaan kelompok sebelum diberi perlakuan. Bila hasil pre test selama empat kali ternyata nilainya berbeda-beda berarti kelompok tersebut keadaannya labil, tidak menentu, dan tidak konsisten. Setelah kestabilan keadaan kelompok dapat diketahui dengan jelas, maka baru diberi treatment. Desain penelitian ini hanya menggunakan satu kelompok saja, sehingga tidak memerlukan kelompok kontrol.Subjek penelitian yang diambil dari penelitian ini yakni 6 anak tunarungu SLB YPTB Malang kelas XI yaitu DR, VT, RM, ST, HH, EM. Teknik sampel yang digunakan dalam pnelitian ini adalah simple random sampling. Data dikumpulkan langsung oleh peneliti melalui observasi dan tes. Observasi yang dilakukan dalam penelitian ini adalah mendeskripsikan pelaksanaan pembelajaran PKPBI dalam Bahasa Indonesia dengan menggunakan metode Sosiodrama terhadap pelafalan kalimat siswa kelas XI yang digunakan untuk mendiskripsikan gejala - gejala yang tampak berupa perubahan - perubahan perilaku yang tampak sebagai dampak dari praktik pembelajaran Pengembangan Komunikasi Persepsi Bunyi dan Irama dengan menggunakan metode Sosiodrama. Setelah itu data diolah melalui teknik analisis, analisis data merupakan tahap terakhir sebelum penarikan kesimpulan. Data dianalisis dengan menggunakan teknik analisis Deskriptif, yaitu berupa penyajian data pre test dan post test.

\section{HASIL DAN PEMBAHASAN}

\section{Hasil}

Dari penelitian yang telah dilakukan diperoleh dua macam data, yaitu kemampuan awal dan kemampuan akhir mahasiswa dalam mengetik. Data kemampuan awal merupakan data yang menunjukkan kemampuan awal siswa sebelum diberikan perlakuan. Data tersebut diperoleh dari tes kemampuan (pre test) yang dilaksanakan sebelum diberikan perlakuan. 
Tabel 1 Hasil Nilai Pre Test

\begin{tabular}{|c|c|c|c|c|c|c|c|c|}
\hline \multirow{2}{*}{ No. } & \multirow[b]{2}{*}{ Nama } & \multicolumn{4}{|c|}{ Nilai pre test } & \multirow{2}{*}{ Total } & \multirow{2}{*}{$\begin{array}{l}\text { Rata- } \\
\text { rata }\end{array}$} & \multirow[b]{2}{*}{ Kriteria } \\
\hline & & I & II & III & IV & & & \\
\hline $\begin{array}{l}1 . \\
2 . \\
3 \\
5 \\
6\end{array}$ & $\begin{array}{l}\text { DR } \\
\text { VT } \\
\text { RM } \\
\text { HH } \\
\text { EM }\end{array}$ & $\begin{array}{l}45 \\
48 \\
49 \\
48 \\
\end{array}$ & $\begin{array}{l}47 \\
47 \\
48 \\
48\end{array}$ & $\begin{array}{l}46 \\
48 \\
50 \\
48 \\
49\end{array}$ & $\begin{array}{l}50 \\
42 \\
48 \\
40 \\
50\end{array}$ & $\begin{array}{l}188 \\
185 \\
195 \\
193 \\
96\end{array}$ & $\begin{array}{r}47 \\
46,2 \\
48,7 \\
48,7 \\
49\end{array}$ & $\begin{array}{l}\text { Kurang } \\
\text { Kurang } \\
\text { Kurang } \\
\text { urang } \\
\text { Kurang } \\
\text { Kurang }\end{array}$ \\
\hline & & & & rate & & & 48 & Kurang \\
\hline
\end{tabular}

Tabel 2 Rata-rata Hasil Nilai Pre Test

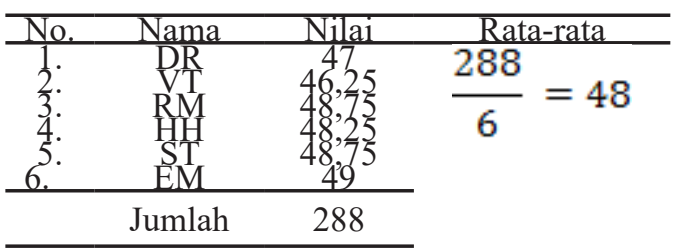

Tabel 3 Hasil Nilai Post test

\begin{tabular}{|c|c|c|c|c|c|c|c|c|}
\hline \multirow{2}{*}{ No. } & \multirow{2}{*}{ Nama } & \multirow{2}{*}{\multicolumn{4}{|c|}{ Nilaipost test }} & \multirow{2}{*}{ Jumlah } & \multirow{2}{*}{$\begin{array}{c}\text { Rata- } \\
\text { rata }\end{array}$} & \multirow{2}{*}{ Kriteria } \\
\hline & & & II & III & IV & & & \\
\hline 1. & DR & 85 & 80 & 80 & 85 & 330 & 82,5 & $\begin{array}{l}\text { Sangat } \\
\text { Baik }\end{array}$ \\
\hline 2. & VT & 80 & 85 & 80 & 85 & 330 & 82,5 & Sangat \\
\hline 3. & RM & 80 & 80 & 80 & 90 & 330 & 82,5 & $\begin{array}{l}\text { Sangat } \\
\text { Baik }\end{array}$ \\
\hline 4. & $\mathrm{HH}$ & 85 & 80 & 80 & 95 & 340 & 85 & $\begin{array}{l}\text { Sangat } \\
\text { Baik }\end{array}$ \\
\hline 5. & ST & 80 & 85 & 85 & 95 & 345 & 86,25 & $\begin{array}{l}\text { Sangat } \\
\text { Baik }\end{array}$ \\
\hline 6. & EM & 80 & 85 & 82 & 87 & 334 & 83,5 & $\begin{array}{c}\text { Sangat } \\
\text { Baik }\end{array}$ \\
\hline & & & & Rat: & & & 93,70 & Sangat \\
\hline
\end{tabular}

Tabel 4 Rata-rata Nilai Post test

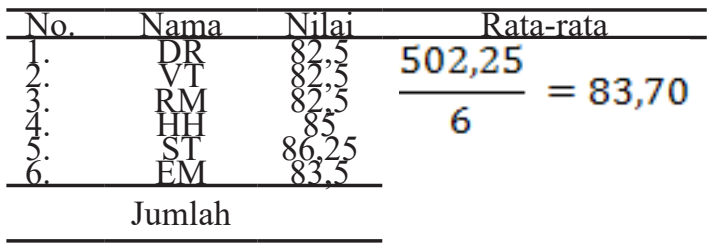

Tabel 5 Peningkatan Kemampuan Melafalkan Kalimat

\begin{tabular}{ccccc}
\hline No & Nama & $\begin{array}{c}\text { Pre } \\
\text { Test }\end{array}$ & Post Test & Selisih \\
\hline 1. & DR & 47 & 82,5 & 35,5 \\
3. & RM & 46,25 & 82,5 & 36,25 \\
4. & HH & 48,75 & 82,5 & 33,75 \\
5. & ST & 48,75 & 895,25 & 36,75 \\
6. & EM & 49 & 83,5 & 34,5 \\
\hline Jumlah & & 288 & 502,25 & 214.75 \\
\hline Rata- & & 48 & 83,70 & 35,7 \\
rata & & 48 &
\end{tabular}

Selanjutnya data kemampuan akhir merupakan data yang menunjukkan kemampuan akhir siswa setelah diberikan perlakuan (treatment). Data diperoleh dari hasil tes kemampuan akhir mahasiswa (post test) yang dilakukan setelah mahasiswa diberikan perlakuan dengan menggunakan treatment metode Sosiodrama. Data kemampuan awal siswa diperoleh dari hasil pre test yang dilakukan sebelum diberi perlakuan. Pre test berupa kalimat dialog malin kundang. Disini peneliti medengarkan apa yang dilafalkan siswa. Kegiatan pre test hanya dilakukan dalam satu kelas saja yaitu kelas XI SMALB B YPTB Malang yang berjumlah 6 orang dengan 2 perempuan dan 4 laki - laki. Berikut adalah hasil pre test tentang melafalakan kalimat sebelum diberikan perlakuan dengan treatment metode sosiodrama. Adapun hasil nilai pre test dapat dilihat pada tabel 2. Berdasarkan tabel dapat diketahui hasil pre test kemampuan awal melafalkan kalimat siswa tunarungu kelas XI yakni mendapatkan nilai rata-rata 48 , nilai tersebut termasuk kategori nilai kurang. Sebelum pembelajaran terlebih dahulu peneliti membuat RPP untuk merencanakan apa yang dilakukan dalam pembelajaran. Bentuk RPP terdapat pada lampiran. Perlakuan dilakukan sebelum post test. Pelaksanaan perlakuan dengan menggunakan treatment metode bermain peran dilaksanakan sebanyak 4 kali yang di laksanakan pada tanggal 10-13 april 2017

Data kemampuan akhir mahasiswa diperoleh dari hasil post test yang dilakukan setelah diberi perlakuan. Post test dilakukan sebanyak 4 kali dengan tujuan untuk mengetahui kestabilan. Dari hasil post test pertama sampai keempat terlihat nilai mahasiswa stabil. Materi yang diberikan pada tahap post test sama dengan materi yang diberikan pada tahap pre test. Post test diberikan setelah siswa mendapat perlakuan dalam pembelajaran melafalkan kalimat. Berikut adalah hasil nilai sesudah diberikan perlakuan (post test) : Berdasarkan tabel diatas, dapat diketahui hasil post test siswa tunarungu di SMALB - B YPTB Malang yakni mahasiswa mendapatkan nilai rata-rata 83,70 , nilai tersebut termasuk kategori nilai sangat baik.

Dalam penelitian ini, setelah mengetahui nilai pre test dan post test maka dilakukan rekapitulasi hasil pre test dan post test yang bertujuan untuk mengetahui peningkatan kemampuan melafalkan kalimat sebelum dan sesudah diberikan perlakuan, rata-rata hasilnya sebagai berikut Berikut ini disajikan hasil rekapitulasi nilai pre test dan post test yang disajikan pada diagram. Adapun hasil rekapitulasi pre test dan post test dapat dilihat pada gambar 1. Berdasarkan gambar 1 diketahui nilai pre test lebih rendah dari nilai post test. Perbedaan yang menunjukkan peningkatan pada nilai post test dikarenakan adanya perlakuan atau treatment metode bermain peran pada siswa tunarungun kelas XI. Selanjutnya data yang sudah di rekapitulasi antara pre test dan post test, data diolah dengan bantuan program aplikasi SPSS for Windows versi 20. Berikut ini hasil dari olahan data yang sudah dimasukkan dalam program aplikasi SPSS for Windows versi 20.

Berdasarkan tabel 4.6 dapat diketahui bahwa nilai minimum pre test sebesar 47 dan nilai minimum post test sebesar 82,50. Nilai maximum pre test sebesar 49 dan nilai maximum post test sebesar 86,25 . Nilai mean pre test sebesar 48 dan nilai mean post test sebesar 83,70 . Selain diketahui nilai minimum, maximum, dan mean, juga diketahui nilai std. deviation. Std. deviation dari pre test sebesar 1.11803dan std. deviation dari post test sebesar 1.58443 . 


\section{Gambar 4.1 Diagram Rekapitulasi Pre Test dan Post Test}

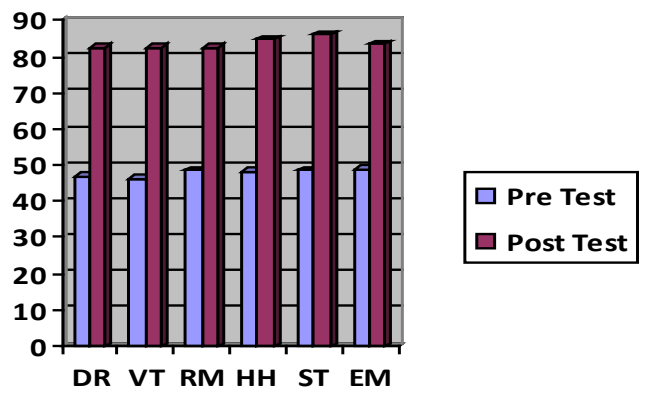

Tabel 6 Descriptive Statistics

\begin{tabular}{|c|c|c|c|c|c|}
\hline & & Minimum & Maximum & Mean & $\begin{array}{c}\text { Std. } \\
\text { Deviation }\end{array}$ \\
\hline Pre Test & 6 & 47.00 & 49.00 & 48.0000 & 1.11803 \\
\hline Post Test & 6 & 82.50 & 86.25 & 83.7083 & 1.58443 \\
\hline $\begin{array}{l}\text { Valid N } \\
\text { (listwise) }\end{array}$ & 6 & & & & \\
\hline
\end{tabular}

Tabel 7 Uji Normalitas

\begin{tabular}{lrrrrrr}
\hline & \multicolumn{3}{c}{ Kolmogorov-Smirnov $^{a}$} & \multicolumn{4}{c}{ Shapiro-Wilk } \\
Statistic & Df & Sig. & Statistic & Df & Sig. \\
\hline Pre & .250 & 6 & $.200^{*}$ & .849 & 6 & .551 \\
Test & & & & & & \\
Post & .277 & 6 & $.166^{*}$ & .816 & 6 & .824 \\
Test & & & & & &
\end{tabular}

Tabel 8 Paired Samples t-Test

\begin{tabular}{|c|c|c|c|c|c|c|c|c|c|}
\hline & & \multicolumn{5}{|c|}{ Paired Differences } & \multirow[t]{2}{*}{$\mathrm{t}$} & \multirow[t]{2}{*}{$\mathrm{df}$} & \multirow{2}{*}{$\begin{array}{l}\text { Sig. } \\
\text { (2-ta } \\
\text { iled) }\end{array}$} \\
\hline & & Mean & $\begin{array}{l}\text { Std. } \\
\text { Devia } \\
\text { ti-on }\end{array}$ & $\begin{array}{l}\text { Std. } \\
\text { Error } \\
\text { Mean }\end{array}$ & $\begin{array}{l}95 \% \text { Co } \\
\text { Interval } \\
\text { Differen } \\
\text { Lower }\end{array}$ & $\begin{array}{l}\text { fidence } \\
\text { of the } \\
\text { ee } \\
\text { Upper }\end{array}$ & & & \\
\hline $\begin{array}{l}\text { Pair } \\
1\end{array}$ & $\begin{array}{l}\text { Pre } \\
\text { test } \\
\text { Post } \\
\text { test }\end{array}$ & -35.70 & 1.409 & 57524 & -37.18 & -34.22 & -62.07 & 5 & .000 \\
\hline
\end{tabular}

Uji hipotesis dalam penelitian ini menggunakan rumus uji t berpasangan (paired samples $t$ - Test). Karena salah satu persyaratan uji $t$ adalah data harus berdistribusi normal, maka sebelumnya dilakukan uji normalitas dengan bantuan program aplikasi SPSS for Windows versi 20

Uji Normalitas bertujuan untuk menguji apakah dalam model regresi variabel terikat dan variabel bebas keduanya mempunyai distribusi normal atau tidak. Dalam pengujian normalitas terdapat dua pilihan, yaitu Kolmogorov-Smirnova dan ShapiroWilk. Kolmogorov-Smirnova digunakan jika jumlah sampel $>50$. Sedangkan jika jumlah sampel $<50$ menggunakan Shapiro-Wilk. Karena sampel pada penelitian ini berjumlah 6, maka cara yang bisa ditempuh untuk menguji kenormalan data adalah dengan menggunakan Shapiro-Wilk jika nilai sig > 0,05 , maka data berdistribusi normal. Uji Normalitas menggunakan SPSS for Windows versi 20. Adapun uji normalitas dalam penelitian ini adalah sebagai berikut.
Shapiro-Wilk menunjukkan bahwa data yang didapat tersebut mengikuti distribusi normal, berdasarkan hasil output menunjukkan nilai ShapiroWilk signifikan pada nilai pre test $0,551>0,05$ dan nilai post test $0,824>0,05$. Dengan demikian, dapat disimpulkan data tersebut berdistribusi normal.

Uji hipotesis dilakukan untuk mengetahui ada tidaknya pengaruh variabel bebas dengan variabel terikat. Dalam penelitian ini, untuk menguji hipotesis menggunakan Paired Samples $t$ Test. Pengolahan data menggunakan SPSS for Windows versi 20. Adapun perumusan hipotesis nihil dan hipotesis alternatifnya sebagai berikut: Ho : Treatment metode sosiodrama tidak berpengaruh terhadap pelafalan kalimat siawa tunarung kelas XI di SMALB B YPTB Malang. Ha : Treatment metode sosiodrama berpengaruh terhadap pelafalan kalimat siawa tunarung kelas XI di SMALB B YPTB Malang. berikut.

Dengan kriteria pengambilan keputusan sebagai

Jika nilai sig. (2-tailed) $>0,05$ maka Ho diterima

Jika nilai sig. (2-tailed) $<0,05$ maka Ha diterima

Berikut hasil penghitungan data dengan Uji $\mathrm{T}$ dengan bantuan SPSS for Windows versi 20. Dari tabel 8 Paired Samples $t$ Test di atas dapat diketahui bahwa nilai sig. (2-tailed) adalah 0,000. Hal ini berarti nilainya lebih kecil dari 0,05 . Sehingga dapat disimpulkan bahwa Treatment metode sosiodrama berpengaruh terhadap meningkatnya pelafalan kalimat siswa tunarungu di SMALB - B YPTB Malang.

\section{Pembahasan}

Intervensi yang diberikan berupa metode Sosiodrama yaitu suatu metode atau permainan edukatif yang yang dimainkan dengan cara berpasangan yang bersifat menantang, (Hadi. 2013 : 11 ) Sosiodrama merupakan salah satu model pembelajaran yang diarahkan pada upaya pemecahan masalah-masalah yang berkaitan dengan hubungan antarmanusia (interpersonal relationship), terutama yang menyangkut kehidupan peserta didik. Salah satu karakteristik siswa tunarungu dalam segi bahasa adalah tata bahasanya kurang teratur. Hal tersebut dikarenakan mereka memiliki keterbatasan dalam menginterpretasikan kalimat sehingga kemampuannya dalam menginterpretasikan hanya bersandar pada pengalaman bahasanya yang terbatas. Manfaat Sosoidrama dalam penelitian ini untuk membantu siswa tunarungu dalam meningkatkan pelafalan kaliamat. Kegiatan penelitian tersebut dilakukan dengan menggunakan metode Sosoidrama dengan interaksi anatar siswa tuna tungu memahami cara berbahasa yang benar, karena selama ini telah kita ketahui bahwa siswa tunarungu sering kali berbicara 
atau berbahasa dengan menggunakan kalimat yang tidak berstruktur atau sering terbolak-balik sehingga orang lain kurang memahaminya, bahkan seringkali mengalami kesalahpahaman antara siswa tunarungu dan orang lain. Penelitian pengaruh penggunaan metode Sosoidrama dalam mengasah pelafalkan kalimat pada siswa tunarungu kelas XI di SMALB-B YPTB Malang menunjukkan bahwa metode yang digunakan dapat meningkatkan kemampuan melafalkan kalimat pada siswa tunarungu. Keadaan ini ditunjukkan pada penilaian kemampuan melafalkan kalimat pada kondisi pre test yang dilakukan selama 4 sesi. Nilai rata rata 6 siswa adalah 48. Pada fase Post tes yang dilakukan selama 4 sesi. Nilai rata rata 6 siswa adalah 83,70.Hasil penelitian ini yang menunjukkan bahwa penggunaan metode Sosoidrama dapat mengasah pelafalan kalimat pada siswa tunarungu kelas XI di SMALB-B YPTB Malang.

\section{KESIMPULAN DAN SARAN}

\section{Kesimpulan}

Berdasarkan hasil analisis dan pembahasan yang telah dipaparkan pada bab sebelumnya dapat disimpulkan bahwa penggunaan metode Sosoidrama dapat memberi pengaruh dalam mengasah pelafalan kalimat pada siswa tunarungu kelas XI di SMALB-B YPTB Malang dengan subjek DR, VT, RM, ST dan HH. Rincian dapat dipaparkan sebagai berikut:Keadaan ini ditunjukkan dengan perubahan skor dari pree test $(\mathrm{O} 1$ - O4) subjek DR, VT, RM, ST dan HH hasil nilai rata rata adalah 48 dan pada post test (O5- O8) hasil nilai rata - rata adalah 83,50 dan yang berarti bahwa post test yang dilakukan dengan menggunakkan metode Sosoidrama memiliki pengaruh yang baik terhadap kenaikan skor dalam mengasah pelafalan kalimat pada siswa tunarungu

\section{Saran}

Berdasarkan temuan peneliti dan kondisi lapangan tempat penelitian, peneliti mengemukakan saran-saran sebagai berikut : (1)Guru diharapkan dapat mengoptimalkan kemampuan yang dimiliki anak berkebutuhan khusus, tertutama pada siswa tunarungu yang mengalami hambatan pendengaran, maka seharusnya kemampuan indera yang lain dioptimalkan yaitu auditorinya. Penggunaan metode Sosoidrama dalam pelajaran Bina Bicara dan Persepsi Bunyi dapat diterapkan karena selain tujuan utamanya adalah melafalkan kalimat, tetapi juga melatih anak tunarungu pada aspek motorik, konsentrasi, kesabaran, dan ketekunan. (2)Mahasiswa Jurusan Pendidikan Luar Biasa diharapkan dapat mempelajari lebih jauh lagi tentang karakteristik anak berkebutuhan khusus sehingga dapat memberikan pembelajaran yang sesuai dengan karakteristik dan kebutuhan anak. (3) Peneliti Selanjutnyadiharapkan dapat mengembangkan penelitian serupa baik dalam ruang lingkup yang tidak terbatas pada anak tunarungu saja. Selain itu, peneliti selanjutnya juga dapat mengembangkan penelitian tentang pengaruh penggunaan Sosoidrama dalam mengasah pelafalan kalimat pada siswa tunarungu.

\section{DAFTAR RUJUKAN}

Arikunto. 2013. Prosedur penelitian. Jakarta : Rineka Cipta

Akbar, Sa'dun. 2013. Instrumen perangkat pembelajaran. Bandung : PT Remaja Rosdakarya Sadjaah, E. 1995. Bina Bicara Persepsi Bunyi dan Irama. Departemen Pendidikan dan Kebudayaan: tidak diterbitkan.

Hadi, syaiful. 2013. Pembelajaran Konsep Pecahan Menggunakan Media Komik Dengan Strategi Bermain Peran Pada Siswa Sd Kelas Iv Semen Gresik. Online jdih, 13 (1) : 11

Kusno. 1985. Pengantar Tata Bahasa Indonesia. Bandung : CV Rosda

Pradipta, R. F., Ummah, U. S., \& Susilawati, S. Y. PENGARUH PENGGUNAAN MEDIA GAMBAR BERSERI TERHADAP PENINGKATAN PENGUASAAN TATA KALIMAT PADA SISWA TUNARUNGU.

Sugiyono. 2010. Metode Penelitian Pendidikan. Bandung: Alfabeta. 